Changing Family Realities in South Asia?

\title{
Contesting the Norm? Live-in Relationships in Indian Media Discourses
}

Fritzi-Marie Titzmann

\section{OpenEdition}

1 Journals

\section{Electronic version}

URL: http://journals.openedition.org/samaj/4371

DOI: 10.4000/samaj.4371

ISSN: $1960-6060$

\section{Publisher}

Association pour la recherche sur l'Asie du Sud (ARAS)

\section{Electronic reference}

Fritzi-Marie Titzmann, «Contesting the Norm? Live-in Relationships in Indian Media Discourses », South Asia Multidisciplinary Academic Journal [Online], 16 | 2017, Online since 04 August 2017, connection on 10 December 2020. URL : http://journals.openedition.org/samaj/4371 ; DOI : https:// doi.org/10.4000/samaj.4371

This text was automatically generated on 10 December 2020.

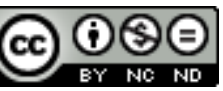

This work is licensed under a Creative Commons Attribution-NonCommercial-NoDerivatives 4.0 International License. 


\title{
Contesting the Norm? Live-in Relationships in Indian Media Discourses
}

\author{
Fritzi-Marie Titzmann
}

\section{Introduction}

1 As compared to premarital dating, which is increasingly acceptable among the urban middle and upper classes in India, live-in relationships pose a far bigger threat because they undermine the sanctity of the bond of matrimony. Cohabitation of unmarried couples has always existed but in the public imagination, it is mostly confined to the extravagant world of film celebrities ${ }^{1}$ or the Hindu pantheon, which includes several extramarital, polygamous and other unconventional couple constellations (Gudermuth 2006).

2 Since 2010, the Supreme Court has ruled that women in live-in relationships should have the same rights as married women. (Yadav and Yadav 2011). Despite a 2015 legal affirmation that such relationships are equal to marriage (Firstpost 2015), controversies in the Indian parliament as well as within society continue. The adversaries' main argument is well known: the unmarried cohabitation is incompatible with Indian culture and values. We thus observe an obvious contradiction between the legal framework and its social acceptance. Media discourses reflect this tension.

3 A recent trend in television advertisements to stage unconventional social constellations -for example, a woman's remarriage (as in an advertisement by jewelry brand Tanishq in 2013)-includes an advertisement released by the tea brand Red Label in 2015, featuring a live-in couple facing an awkward family situation that eventually dissolves into intergenerational harmony. The one-minute commercial visualizes not only an alternative to the married-couple situation but invites us to re-imagine the relationship between parents and children as well. Based on the assumption that society and media co-construct each other, this article asks whether the act of rendering the 
unconventional visible is already a challenge to the idea of the Indian family. The coconstruction of media and society can be understood through the concept of medialization-or "mediatization"-which is currently being discussed in divergent ways as a meta process of socio cultural change. The term describes an increasing media influence on different social and cultural spheres (Hepp 2009; Kim 2008; Bergmann 2006). The key argument is that increasing medialization and socio-economic change reciprocally impact each other and thus co-construct social, cultural, and economic dynamics. Therewith, the medialization approach is a clear deviation from onedimensional modernization-theory approaches. Media shape our lifeworld as content, and we as media recipients or media producers interpret, appropriate, and in many cases design this content.

Similarly to the above stated research question (whether visibility of the unconventional is already a challenge to the idea of the Indian family) referring to the encoded messages of advertising, a discussion about the reciprocal relation between visibility and social acceptance takes place around queer sexualities in South Asia. Gugler traces the development of formerly negative or ridiculing representations of marginalized sexual minorities on mainstream media towards more positive and balanced depictions and news reporting (2014:150f). He argues that an increasingly medialized discourse renders alternative sexual identities more visible and thus impacts the legal process negotiating legality versus criminalization of homosexuality.

5 Using a media culture perspective, this article further analyzes the conflictual online discourse evolving around the Red Label short film. In particular, looking at viewers' comments reveals conflicting attitudes that reflect discursive trends in Indian society, although the validity of the findings is necessarily limited to a certain section of society and based on exemplarity analysis, rather than big data. ${ }^{2}$ On the one hand, the concept of live-in relationships is regarded as a welcome and progressive development, even though it is considered a "western" concept that has influenced Indian society. On the other hand, concerns about the decline of the family system and the rise of a commitmentphobic generation are expressed by self-proclaimed conservatives as well as YouTube users.

6 This article is structured in three parts. Part I serves as an introduction into the social and legal reality of cohabitation in India and the connected discourses. Parts II and III contain the Red Label case study. In analyzing the advertisement and its audience's responses, I loosely follow Hall's approach of encoding/decoding, whereby production is considered as encoding meaning whilst the audience decodes it: "In a 'determinate' moment the structure employs a code and yields a 'message': at another determinate moment the 'message,' via its decodings, issues into the structure of social practices." (Hall 2006:165). Hall delineates how the meaning structures of production and reception do not necessarily correspond symmetrically (2006:166). While all media production encodes meaning which consequently circulates into the discursive sphere, decodings do not inevitably follow from encodings (Hall 2006:171). Decoding is shaped by social and economic relations which in turn influence how the media message is translated into the discursive sphere and into social practice. Some codes have been "naturalized" and have become part of the dominant-hegemonic discourse (Hall 2006:167). In the case of the Red Label advertisement, gendered markers of Indianness and "good" behavior fall into this category. Other "signs" of advertising language are read in highly ambiguous and polysemic ways and reinforce Hall's argument that there is "no necessary 
correspondence" (2006:171) between encoding and decoding. This paper is structured into three parts. Following an introduction to relevant discussions (Part I), the Red Label case study is divided into two parts in order to understand the potentially conflictual dynamics of meaning production. Hence, Part II analyzes the advertisement in an attempt to locate the encoded meaning and connect it with a critical assessment of seemingly "progressive" advertising in competition with the industry's inherent capitalist intention. Naturally, my own academic, ideological, and personal positioning comes into play here and determines my "reading" and analysis. Part III analyzes viewers' comments on YouTube and contextualizes their decoding positions within larger social and academic debates.

\section{Live-in relationships: legal situation, social reality and media/culture discourses}

7 In India, unmarried couples have been considered equal to married couples in terms of rights since 2010. For example, an unmarried woman is entitled to inherit her deceased partner's property. ${ }^{3}$ In a further landmark judgment on April 13, 2015 the Supreme Court ruled that couples in live-in relationships will be presumed legally married (Firstpost 2015). Despite these progressive judgments, controversies around the moral validity of cohabitation continue to polarize Indian society. Marriage continues to be the most important rite of passage and secures the viability of the lineage through procreation. Generally speaking, hardly any event is more important in South Asia than the wedding and the celebration usually takes on a very public character to announce the new family alliance. It functions de facto as an initiation into adulthood and actualizes the transition into entirely new social roles. In his work on Hinduism, Michaels states that premarital sexuality, illicit children and the dissolution of a relationship appear even more problematic given the public aspect of marriage and the associated rituals (2006:128). However, acts that occur in an accepted realm of silence are somewhat excluded from this proposition. ${ }^{4}$ Therefore, heterosexual marriage as a normative and exclusively acceptable relationship model is hardly ever challenged. One exception would be the initiative "Vina Mulya Amulya Seva" (Invaluable Service Without Any Price), that provoked nationwide attention. ${ }^{5}$ Natubhai Patel founded a non-profit organization in Ahmedabad in order to bring elderly singles together, with the aim of creating marital or live-in relationships. "There is no maximum age for marriage. No-one can stop two adults from living in either," a BBC photo reportage quotes the founder (BBC News India 2012). Patel started the organization after the devastating 2001 earthquake in Gujarat which left -in addition to a total death toll of around 20,000-many people widowed and without family; thus the initiative is welcome and increasingly popular. Moreover, it does include widowed and divorced senior citizens in its matchmaking attempts. The propagation of remarriage, especially for widowed Hindu women, is particularly noteworthy since it breaks traditional taboos and may be read as a signifier of slow social change. On the other hand, the fact that "Vina Mulya Amulya Seva" exclusively targets senior citizens makes clear that this particular space is created for those who are, due to their age and connected social status, no longer subject to social rules in the same way as young people. Young people are just beginning to fulfill their expected social roles. For them, the "right" marriage significantly influences social status during adulthood. 
Given the ritual and social importance of marriage for the entire family, unmarried couples often lack the blessing and support of their families. Furthermore, they face practical problems such as renting a house or staying in a hotel room together (Chatterji 2015). Recently, the Delhi-based start-up StayUncle was set up in order to help couples renting a room in Indian metro cities (Balachandran 2016). ${ }^{6}$ Such initiatives originate in response to increased moral policing and persistent opposition to unmarried couples living together within parts of Indian society (Brosius 2013:266ff). One of the most prominent cases of moral policing is the infamous Aksa Beach hotel raid (August 6, 2015) on Madh Island and at Aksa Beach in Mumbai, where around 40 couples staying in hotel rooms were arrested and charged with "public indecency" according to section 110 of the Bombay Police Act ("Behaving indecently in public" from 1951). The couples were held in police custody for nearly five hours and charged with a fine of Rupees 1,200. Three cases were also registered under the Prevention of Immoral Trafficking Act that pertains to prostitution (Devnath 2015). Being a very drastic example, the incident immediately led to outcry in the media and furious debates among citizens and politicians, online and offline. ${ }^{7}$ Above all, it generated a discussion over ideas of public and private space. The critics' fundamental argument is that public intimacy and certain behavior by women (e.g. drinking) is morally wrong, even socially destabilizing. Several authors have noted that displays of affection might be acceptable in certain "privatized/modern public space" (malls or coffee shops) that are clearly marked as middle class. But intimacy in public parks renders less-privileged couples more vulnerable, as their exclusion from the above mentioned "privatized/modern public spaces" additionally reveals a classist division in moral judgment (Brosius 2013:271f; Phadke 2007:1514):

Individual emotions are said to colonize public space and hurt the sentiments of a moral community .... Within this interpretation, pleasure becomes lust and obscenity, and lovers in public become public nuisances and an insult to conservative moral values (Brosius 2013:270).

Against this background and the ever-lurking danger of physical attacks, unmarried couples often lack privacy, acceptance and safety. We thus observe an obvious contradiction between the liberal legal framework and social reality. Nevertheless, following the legal recognition, a growing visibility of live-in relationships in the media is observable. News media have reported extensively and overall approvingly on legal proceedings regarding the status of live-in relationships since Indian courts ruled them legal in 2005. ${ }^{8}$ Television serials and movies ${ }^{9}$ increasingly broach the issue and a widely aired television advertisement picked it out as a central theme, as I will show later on. The growing medial visibility creates an impression of growing social acceptance, but discussions and debates taking place in response to media content mirror social anxieties and suggest that something uncomfortable persists. Commentary functions in online media constitute a very interesting source for a new form of audience or readership studies. As Chauhan has shown with his India-based study on advertising language, media is an integral element of modern culture and society and advertising holds a peculiar position between marketing-driven intentions and hidden messages (2010), or in Hall's words "encoded meanings" (2006). Although a more comprehensive analysis of a variety of media sources would be preferable, the following case study of Red Label's tea advertisement and the online responses it generated reflect most of the dominant discursive themes I have identified so far in academic and public discussion. 


\section{Progressive Advertising? Red Label's "Surprise Visit" (2015)}

the company Brooke Bond Red Label also posted the advertisement via its official account the company Brooke Bond Red Label also posted the advertisement via its official account on YouTube and added the description: "Can hospitality melt away the differences? Watch the heartwarming film of Red Label tea and find out. It's a story about old and new. About relationships and conflicts. About tea and togetherness." 10

10 The one-minute commercial's storyline is rather simple. The short film opens with an elderly couple ringing at their son Chirag's door to pay him a surprise visit on his birthday. The first sentence uttered by the mother includes a comment on his pale looks with the promise to get him a wife soon. ${ }^{11}$ Suddenly, we see a girl brushing her teeth appearing in the background, accompanied by melancholic guitar music, which creates an uncomfortable moment rife with anxieties about what will happen next. She is eventually introduced by Chirag to his parents as Pallavi with whom he is living. The mother's smiling face immediately drops to an unbelieving expression and she watches every move Pallavi makes with consternation. The awkward situation is finally dissolved by Pallavi who quickly puts on a dupatta, ${ }^{12}$ rushes into the kitchen and prepares tea for the utterly surprised parents. She not only serves them but even considers the father's diabetes and the mother's preference for two spoons of sugar. After confirming that she added cardamom to the tea as well, Chirag's mother is finally pacified and concludes that Pallavi's tea is not bad. Indicated by the music getting louder and more cheerful, the audience thus witnesses a nearly scandalous situation dissolving into intergenerational harmony and the hope of mutual acceptance through a cup of good tea.

Red Label uses a controversial topic to equip its consumer-good with associations of social progressiveness and therein employs a marketing strategy that seemingly encodes a social message into the advertisement. Research on advertisements has shown, that "[b]eyond the objective to sell products and services, advertising is noted to affect social attitudes, define social roles and influence cultural values" (Gabler 2010:2). Red Label had already gained attention in the past for its socially progressive commercial titled "Neighbors," in which Hindu and Muslim neighbors share a cup of tea and thus create intercommunal harmony. ${ }^{13}$ Advertisements with messages that are interpreted as driving social change can be found in other commercial branches apart from tea advertising as well. Tanishq, an expensive jewelry brand, aired a television commercial displaying the remarriage of a Hindu woman and the groom's acceptance of her daughter from a previous marriage. ${ }^{14}$ Following Gabler's argument, images of gender roles and the formation of the couple are constituted through public imagination, which is strongly influenced by mass media, including advertising (2010). But as we see in "Surprise Visit," discourses on couples transcend gender constructions and touch on multiple other social constructions, e.g. the parent-child relationship (Chirag and his mother), the couplefamily relationship (Chirag and Pallavi towards his parents), and even more generally the idea of the collective. Red Label is not the only Indian brand to cash in on the representation of live-in relationships. The fashion brand Anouk ${ }^{15}$ as well as the real estate website 99 acres $^{16}$ have increased the visibility of cohabitation by presenting it as part of daily life. The Anouk advertisement is particularly notable because it features a lesbian couple getting ready to be introduced to the visiting parents. It thereby

South Asia Multidisciplinary Academic Journal, 16 | 2017 
additionally breaks the taboo on homosexuality. Referring to the 99acres advertisement, a blogpost on swener.com reads:

Capturing the growing trend of live-in in the urban areas, 99acres.com has cashed in on the concept pretty well. As the room-mate announces his girlfriend would be moving in with him, the guy is left clueless for finding an apartment. Friends form a major part of our social circle, and the way the guy accepts the girl moving-in with his friend, shows the changing perception of the society as well. (swener.com)

It is of course debatable whether advertising does in fact mirror the "perception of the society," as the blogger above claims. Nevertheless, Hall has remarked that "though the production structures of television originate the television discourse, they do not constitute a closed system. They [on] draw topics, treatments, agendas, events, personnel, images of the audience" (2006:164). Following his argument, the audience is both source and receiver of the encoded message. But just as significantly, the companies promote themselves as agents of social change, a stance which resembles the traditional postindependence Indian governmental attitude towards media production. ${ }^{17}$ The didactic entertainment of the nation-building era transforms into consumerism with a social message in post-liberalization India. The emphasis on this interpretation lies in the psychological aspect of capitalism, which advertising may trigger. Television commercials such as the ones discussed above actualize affective reactions, a phenomenon which in turn generates clicks, likes, or higher ratings, translating into capital profit. Thereby, advertising companies simply employ the postindustrial logic of information capitalism, where the creation, distribution, use, and manipulation of information is a significant economic, political, and cultural activity. ${ }^{18}$

Phadke argues, focusing on the growing visibility of explicit sexuality in Indian advertising, that mere visibility does not enhance a growing acceptance of individual sexual desires but more a consumerist commodification. She uses the term "sexual transformation" as distinct from sexual revolution because changes are driven by a market-oriented media and consumer-goods industry (Phadke 2005:75). Although what we see in "Surprise Visit" is not explicit sexuality, I suggest that Phadke's argument may be applied to the Red Label advertisement as well. To encode an aspect of social transformation that still does not create a major friction with existing social practices, yields good commercial success for the product that is being marketed. Hence, the advertisement itself does not challenge the idea of the Indian family, although it is perceived this way by many viewers.

13 Another interesting example is a recent Indian television commercial for Tinder, a popular global dating app, where a mother approves of her daughter going out on a date. While being celebrated as groundbreaking by some, others criticized the stark resemblance to matrimonial advertisements ${ }^{19}$ and mocked Tinder for "going desi" 20 (Nettikkara 2016). The idea remains that the daughter eventually has to have a heterosexual monogamous marriage. The commercial's tribute to modernity is her going out and finding that man. This perspective intersects with the image of the "New Indian Woman," a concept that has been constructed and mediated by the media since the 1980 s (Mankekar 1999 and 2009), although it was first located within colonial nationalist discourses (Chatterjee 1989). ${ }^{21}$ The contemporary "New Indian Woman" pursues a global lifestyle but sticks to "Indian values"; she combines tradition with modernity and stays "Indian at heart" (Chaudhuri 2001; Fernandes 2000; Mankekar 1999; Munshi 1998). I have argued elsewhere that this image is found in the aspiring middle and upper classes which constitute the prime target group for online matrimonial advertising 
(Titzmann 2011a:54). The Tinder advertisement follows a similar principle by showing the daughter going out on a date in line with her mother's expectation of her finding an eligible groom.

14 Based on a decoding of what I perceive as visual sub-codes that mark a gendered Indianness in the dominant-hegomonic discourse, Pallavi in "Surprise Visit" adheres to certain "Indian values" by putting on a dupatta and attempting to please her possible future in-laws with her skills of servitude and hospitality. ${ }^{22}$ The fact that she is challenging the norm by living in with Chirag recedes to the background. Both protagonists manage to balance their modernity with a simultaneous Indianness. In summary, the advertisement is open to multiple interpretations. The progressiveness of taking up a counter-normative constellation with the depiction of a live-in relationship cannot be denied, while the didactic of social advertising is reminiscent of preliberalization developmental television. On the other hand, advertising is essentially embedded in consumer capitalism. One could conclude by calling Red Label's strategy consumerist progressivism..$^{23}$ While I decode the advertisement's progressivism as a clever marketing strategy and attempt to point out the subversion's limitation, viewers respond strongly to the "hidden messages" they detect in the short commercial.

\section{Viewer Interpretation}

The following section takes a closer look at how viewers interpret the Red Label commercial. The analyzed sample included all posts made until October 30, 2015, which amounts to 65 analyzed comments (including replies to comments). On April 7, 2017 the video had 101,419 views, 250 likes, and 29 dislikes. 30 different registered YouTube users posted below the video and from an interpretation of their user names the numbers of male and female users are almost equal. 12 names appeared male, 13 female and 5 could not be related to any gender. However, user names are chosen freely and might not reflect the actual gender of the person. Among the defining characteristics of social media platforms like YouTube are interactivity and non-verifiable authors. Both pose challenges to existing textual-analysis approaches. Interactive functions can be taken into account via the traceability of discussion threats rendering possible an exploration of dialogical discussions emerging between two or several users. But as Jayachandran in her methodological discussion on the analysis of reader comments to online news observes, "[t]he anonymity afforded through concealing identities while commenting could result in 'utterly aggressive content' that impedes constructive discussions" (2015:48). She further refers to studies concluding that writing under pseudonyms lowers the intellectual quality of the comments as well as the author's responsibility for them (Jayachandran 2015). ${ }^{24}$

16 The analytical methodology applied in this paper consists of textual analysis in an attempt to understand the decoding positions of viewers who commented on YouTube. I have generated the main themes following the grounded-theory approach which corresponds to Hall's understanding of decoded messages (Mey and Mruck 2007; Hall 2006). The findings generated through this method can be grouped into two thematic clusters: "Gender roles and the family" and "Indian culture versus 'Westernization," both of which will be explored in the following sections. 


\section{Gender roles and the family}

17 The most discussed topic among the viewers' comments was the girl's behavior. Comments were more or less unanimous in the observation that Pallavi perfectly fulfills her prescribed gendered role. As mentioned above, by serving tea she adheres to principles like servitude, demureness and hospitality that are conventionally expected from a daughter-in-law. A viewer comments: "yeah, the girl getting tea part is not good... too clichéd" (Kakul Singh). ${ }^{25}$ Another one writes: "I'm sure several people especially pseudo feminists kinds will still have the problem with the girl getting the tea" (raina1161) and receives a reply from Agratha Dinakaran: "Well, I'm yet to see an ad where guests come over, and it's the boyfriend/husband who rushes to the kitchen to get tea and snacks."

18 Several viewers also asked what would have happened if these were the girl's parents and came to the conclusion that a live-in relationship would have been even less acceptable from this perspective, therewith confirming different gendered standards within society that are mirrored in the narrative of the commercial. Widely discussed is the symbolic meaning of Pallavi putting on a dupatta before serving tea to her boyfriend's parents. While some commenters are confused about the implied message, others identify the dupatta as the crucial turning point of the narrative: "what part shows her SANSKAR-a dupatta of her OR live with her boyfriend i $m$ confused western style with indian touch...........incredible indian" (bhordia).

Sanskār (संस्कार) is a Sanskrit term used in Hindi that translates literally as a "sacrament," which is celebrated in a particular rite but denotes culture and tradition. The confusion about how to categorize the advertisement-as "western" because it features a live-in relationship or as "Indian" because the girl wears a dupatta-is indicative of how strongly certain ideological constructions are connected to markers of appearance and an imagined "westernization." Another viewer replies to this comment: "One dupatta holds all the sanskaars" (Rahul Shankhwar). The above-discussed, highly-gendered, visual symbol and behavioral pattern are apparently decoded by most viewers in line with a dominant cultural discourse of Indianness, similar to my interpretation in Part II. Nevertheless, the confusion regarding the intended meaning reinforces Hall's argument of media products' polysemic value and multiple possible positions of decoding.

Women's double role as earners and housewives connected to a discussion of equality in relationships is another topic that would come under the overarching theme of gender roles in this analysis. The perceived simultaneous modernity of the relationship together with the strongly gendered performance is a starting point to criticize differing expectations towards men and women: "It just shows that despite everything, women are still expected to, and will be judged on their roles as domestic wives." (Agratha Dinakaran).

21 It is striking that the discussion of gendered roles immediately becomes a battleground between defenders and attackers of feminism as well as ideas of gender equality. From a feminist point of view, the stereotypical depiction of the entire social scenario is to be criticized for its representation of women as obedient and homely. The above quoted comment by raina1161 on "pseudo feminist's kind" already indicates a strong prevailing discomfort associated with the label feminism. A considerable part of the thread of posts consists of a paradigmatic discussion between three users (raina1161, Agratha Dinakaran, 
Sectum Sempra) who fight over ideas of gender equality and their interpretation of the commercial. Again, viewers' comments reveal oppositional decodings of the same "product," presumably depending on their own gendered and ideological positionality. Their conversation unfolds mostly dialogically via the reply function. It starts with Agratha Dinakaran, whom I have identified as female according to her user name, and who is insulted after criticizing the advertisement as stereotypical because of the strongly gendered roles: "instead of ranting about the video, make your own video with your bf bringing your parents the tea cup" (Sectum Sempra to Agratha Dinakaran). From that point onwards, the discussion increasingly escalates:

Something as simple as raising a point of not showing enough men helping out in household chores is a rant now. Kind of explains why Indian men actually do the least amount of household work in the world. :) (Agratha Dinakaran to Sectum Sempra).

Even with all this feminazi bullshit going on these days, I have rarely seen any couple in which the woman is earning more than the man. ... Now, if the guy is earning more, the girl is supposed to be more involved in the domestic work. Makes sense? The commercials which shows a woman bringing a cup of tea, also shows she is a housewife, which is equality (Sectum Sempra to Agratha Dinakaran).

In this comment, the emphasis does not lie on a division of male and female skills or chores but on the viewer's understanding of equality in terms of an equal distribution of work. The viewer does not want to stand out as a misogynist but simultaneously exposes a deep-rooted aversion to feminism. An entire movement of women's rights is dismissed by comparing it to Nazis and the term feminism is being used as an insult. The debate eventually leads to a point where not only is Agratha's criticism laughed at, but she is accused of "harming everyone":

You are looking only at the bad apples, and I this is really harming everyone. This video had nothing to do with feminism, but you made it that way. Stop poisoning everything (Sectum Sempra to Agratha Dinakaran).

It is not made clear who or what exactly she is meant to harm or poison but one possible interpretation is that the strong rejection of anything perceived as "feminist" also includes a fear of feminism as a destructive force that challenges and unsettles social standards. Shilpa Phadke argues that it is important to note the difference between feminism and gender equality:

The discourse of equality is the easiest one for the state, for instance, to support, propagate, and attempt to institutionalize. Feminism(s), however, while they would include the idea of equality, are also a political critique of patriarchal power relations, and focus on the transformation of structures and institutions (Phadke 2015:64).

She contextualizes her article within a globally resonant discourse that young women nowadays actively distance themselves from feminism and elaborates on her own classroom experience teaching gender studies: "For young women, their feminism is precarious because it places possible heterosexual romance at risk by marking them as 'anti-men,' or so they perceive. Further, it often places them in an antagonistic position with their families" (Phadke 2015:64f). While leaving open the question of which gender is hidden behind the user name Sectum Sempra, the strong antagonism could well be understood within Phadke's explanation. ${ }^{26}$ Viewers vividly discuss whether the depicted scenario seems realistic or not. The majority agree that the commercial does not reflect a realistic intergenerational relationship and that the easy acceptance of the live-in scenario is rather wishful thinking. ${ }^{27}$ Nevertheless, the effort to encourage social change is welcome and positively commented upon: "The ad is good and highlights a new age of 
parents" (raina1161). Remarkably, the normative framework of the highly hierarchically structured Indian family system pervades viewers' interpretation. Given the social power structure, parents need to change in order to render social change possible. Viewers decode this effort as the inherent social message of the advertisement: "That's what they are trying to change... parents ki mentality that it's okay!" (TheFreeSpiritedSoul).

\section{Indian culture versus "Westernization"} "western" culture from "Indian values." Viewers relate to the structure of the traditional joint family, whereby several generations live under one roof, as Indian and perceive a live-in relationship as the "western" opposite: a nuclear and individualistic relationship of two people, often without the blessing of their respective families. "Are some young Indians way to cool to live with there families now? Gora ${ }^{28}$ wannabes" (SuperKing604), criticizes a viewer. Others go even further by accusing Red Label of threatening the traditional value system: "dumb is this company to buy such creative ideas destroying the value system of the culture" (Deepak Lanka).

the core of the above quoted complaints lie anxieties around westernization, mora breakdown and the loss of tradition. The family as the most important social institution stands as a fortress of tradition and morality to be protected against alien influences and decay (Dasgupta and Lal 2007; Poggendorf-Kakar 2003; Uberoi 2003):

[P]ublic opinion in India has been obsessed with the spectre of the imminent breakup of the Indian joint family system through processes of urbanization, industrialization, westernization, individualization, and the liberation of women (Uberoi 2001a:327).

In anthropological literature, India is considered the prime example of a functioning "Joint Family System." Based on Sanskrit scriptures, indological research has interpreted the joint family as the traditional family form of India. Despite the general acceptance of the symbolic importance of the Indian joint family, the definition, composition, functions, history, and future of the concept remain unclear. Although its decline has been predicted since the colonial era with much pessimism (Uberoi 2003:1062ff), most authors agree that the Indian family, particularly embodied in the joint family system, represents an ideological construction and code of conduct rather than a specific household formation (Dasgupta and Lal 2007; Uberoi 2003).

More recent studies have emphasized the roles of individuals and families as factors for change and social mobility as opposed to earlier studies focusing mainly on the caste system (Kaur and Shruti 2016; Sharma 2011b). Nevertheless, the joint family as a "traditional" ideological construction remains and is also closely tied to political ideas that stress the primordial Hindu identity of India and its social values and norms (Poggendorf-Kakar 2003:179f). It finds consistent confirmation within popular Hindi cinema (Uberoi 2001a). Another political aspect is the equation of the Indian family with the nation. Family rhetoric is central to nationalist discourse, exemplified by the conceptualization of "Mother India" (or the goddess Bharat Mata) and expressions like "the global Indian family." ${ }^{29}$ Poggendorf-Kakar stresses the Hindu nationalist connotation of the contemporary discourse around "Mother India" but she also notes that the metaphor of the nation as goddess can be traced back to a synthesis of nationalism and Shakti worship in $19^{\text {th }}$ century Bengal (2003:184f). Following this logic, the nation is conceived as a family and the family is conceived as the core cultural principal of Indian

South Asia Multidisciplinary Academic Journal, 16 | 2017 
society. Former Indian President Abdul Kalam co-authored a book titled "The Family and the Nation" (Mahapragya, Jainulabdeen, and Kalam 2014). The book cover reads: "Only a strong and happy family can lead to the birth of a noble nation," thus further perpetuating the nation-family nexus.

The discussion about the east/west divide essentially circles around the superiority of relationship models, wherein so called "arranged marriages" are thought of as culturally Indian and "love marriages" or live-in relationships are attributed to a "western" interpretation of modernity. Meena Khandelwal has dealt extensively with the assumption that in the "West" people marry out of love, while in the "East" marriages are arranged (2009).

Arranged marriage exemplifies the problem of exaggerated cultural difference. It is constituted by both material needs and popular discourses of love, marriage, and family. It occupies the intersection of gender and nation, and is described as an exotic cultural practice in the United States, and signifies "family values" in Indian communities (Khandelwal 2009:584).

She further argues that this logic clearly shows orientalist streaks. However, she points out that in the case of marriage the "East" is constructed as rational and the "West" as irrational. In orientalist discourses the distribution of attributes is usually the reverse (Khandelwal 2009:586). The juxtaposition of free romantic love with arranged marriages proves untenable. Dating, argues Khandelwal, does equally maintain socio-economic stratification. Most marriages in the USA and European societies are contracted within socio-economic classes and not across. Despite a rhetorical shift from material concerns to love, social reproduction remains the pivotal function of marriage within nearly all social and cultural contexts (Khandelwal 2009:592). In regards to the Indian context, Mody rejects the distinction between love and arranged marriage in favor of a classification that distinguishes between personal and social choice (2006). The Red Label commercial not only appears to bring out the east/west and arranged/love divide, but the debate is also highly judgmental and emotionally charged. Self-proclaimed experts like the viewer Ayla Balaga clearly demarcate what is morally and socially of higher value from their point of view:

im a social psychologist who has worked in the states...n I have specifically studied such relationships \& hv compared more conservative relationships ... If you see the western lifestyle... $\mathrm{n}$ then view the statistics... its shocking how many relationships are constructed... even they started with the whole idea of "live in" relationships decades ago.... The thing it won't stop there.... Just keeps getting worse $n$ out of control... now hookups $\mathrm{n}$ even online prostitution (Ayla Balaga).

While looking closer at the discourses taking place around live-in relationships in the wider online sphere, the accusation of delaying commitment by not wanting to marry is a recurrent theme. A blogger by the name Samiksha Wadhwani writes:

If an analysis is made of need of such relationships, avoiding responsibility would emerge as the prime reason. The lack of commitment, the disrespect of social bonds and the lack of tolerance in relationships have given rise to alternative to marriages (Wadhwani 2013).

Similar accusations are not unfamiliar in a global popular discourse: the thirtysomethings of today are often called the undecided generation suffering from fear of commitment. ${ }^{30}$ The sociologist Eva Illouz has argued that a fundamentally capitalist logic of consumer choice can be seen as an explanation (1997). Too much choice results in having difficulties committing oneself because of the ever lurking thought that something better could come up. Hence, it comes as no surprise that most of the pro- 
cohabitation groups and posts contain references to liberalism, choice, freedom, and individualism. ${ }^{31}$

In her comment, Balaga argues that high divorce statistics and moral decay-e.g. "hookups"32 and "online prostitution"-are the eventual outcomes of live-in relationships compared to "conservative relationships," i.e. marriage. As indicated in her comment, sexuality is closely related to the issue of culture and western influence. In this line of argument, live-in relationships refer to illicit sexuality and threaten the priority of controlled (female) sexuality. The holy bond of heterosexual matrimony forms the basic module within the above-discussed family conceptualization. Unconfined sexuality, consequently, undermines the moral superiority of the entire construction. Cohabitation, which is imagined inclusive of sexuality outside wedlock, as well as unmarried couples being sexually intimate in hotel rooms or public spaces, appears to threaten the values connected to the family's symbolism, thereby threatening Indian culture. Recent incidents of moral policing indicate an overall hostile attitude towards relationships outside marriage. Balaga's comment thus points to her perception of an encoded threatening "message" in the Red Label advertisement. Her own reading is situated within the normative discourse on the Indian family system and its entanglement with nationalism and morality. Within this context, many scholars have noted that women's sexuality is the main site of anxiety. Mankekar links female sexuality also to middleclassness:

[A]spirations to upward mobility into the middle class were frequently expressed in terms of a greater preoccupation with female modesty and respectability and, in many cases, an increased surveillance of women's sexuality (Mankekar 2004:411).

Bearing in mind women's responsibility to protect and reproduce the symbolic Indian family, her respectability signifies not only her personal virtue but also that of the nation. ${ }^{33}$ Challenges to the normative family are therefore highly uneven along gendered lines, as the roles of Pallavi and Chirag in the advertisement clearly indicate. Feminist scholarship has particularly critiqued the institution of the family for being heteronormative, patriarchal, exclusionary and hierarchical (Shah 2015). ${ }^{34} \mathrm{~A}$ perceived breakdown of patriarchy is therefore often decoded in terms of moral decay. Similarly to Balaga, another viewer paints a scenario of ever-increasing moral deterioration if commercial advertisements continue to feature norm-breaking social settings: "What's next in this series? Parents visiting during a gang bang and enjoying a cup of tea made by a stripper in a dupatta?" (Rahul K).

Within the highly controversial debate about what constitutes Indian culture and which morality is valid, viewers express strongly diverging decodings.

I think they are promoting acceptance of love, in whatever form it may be. Live-in isn't immoral, it is two people who love each other staying together and living a happy life. I sometimes worry how twisted our definition of virtues and principles are. Love. Live. Share. Care. that is what morals should be judged on, on pseudo ideas of what we consider culture, defining Indian culture via such constructs only brings bad name to the culture (Irene).

Interestingly, in this comment Irene challenges monolithic and conservative morality apostles but simultaneously expresses the intention of not bringing a "bad name to the culture." What stands contested is again the idea of Indianness in relation to sexuality and morality. 


\section{Conclusion}

29

In summary, I grouped viewers' discussions on gendered roles, feminism, ideas of equality and the role and behavior of the parents under the cluster "Gender roles and the family." The second group of themes mostly included debates on Indian culture as opposed to the "West" with a particular focus on sexuality and relationship models. As the discussion illustrates, viewers are apparently confused about the exact message conveyed by the advertisement. Some read it as an emancipatory, liberating move towards a more egalitarian representation in commercial television; others decoded an inherently dangerous message aiming to destroy the dominant social fabric; and a third group of commenters is still not satisfied with the level of progressiveness and criticizes the authenticity of the representation. The research for this paper did not include an interrogation of the advertisement's producers who could have provided further clarification about the (intended) encoded meaning. However, this was not the initial intention. This paper rather asked whether the act of rendering the unconventional visible is already a challenge to the idea of the Indian family. The answer can only be an ambiguous one as the subversion of the norm remains limited, both because the advertisement articulates counter-normative (live-in relationship) and normative markers (stereotypical gender roles), and because advertising is generally embedded in consumerism. The encoding/decoding approach thus reveals asymmetrical meaning structures of production and reception as well as polysemic decodings by the audience. The protagonist Pallavi fulfills the image of a caring, quiet, adaptive and family-oriented bride-to-be, and by indicating chastity with the dupatta that she puts on, she confirms conventional notions about gender norms. It is, as the YouTube discussion clearly points out, not the son but she who has to convince his parents of her value. Therewith, the commercial resembles similar ones that feature typical situations where the boy's parents come to see a possible bride. As Rajeswari Sunder Rajan (1993) argues, commercial advertising redefines the themes that are the traditional terrain of women's movements. Issues like sexuality, marriage and family are dealt with in a conflict-free and harmonious way. "Advertising targets the most frequent sites of women's oppression-sexual harassment, domestic work, dowry demands, marriage rituals, the joint family-and redefines them in glamorized or, alternatively, trivialized terms as the sites of remaking female identity" (Rajan 1993:132). "Surprise Visit" conforms to the same ideal as commercials that feature women as protagonists to advertise kitchen equipment or healthy products for the entire family. Modernity remains superficial and merely technical. Red Label's modernity is implied in the message of "soft" cultural change through the representation of an unmarried couple. But it does not negate the factuality of a television advertisement trying to sell a tea brand. The logic of advertising, Phadke argues, transforms the appeal of products from the rationality of utility to the aspirationality of social status (2005:69). That means the message shifts from "buy this product, it's useful" to "buy this product and it will make you modern, progressive and yet retain your Indianness." This again is connected to the very logic of information capitalism and advertising's affective potential. "Click capitalism" seems to work well in the case of "Surprise Visit." The emotional uproar created by the commercial has made Red Label's marketing strategy successful. 

are deeply embedded in representations of the nation. Cohabitation poses a threat to ideological constructions of an essentialized "Indian family" and several entangled discursive themes such as (female) sexuality, relationship models, and intergenerational relationships yield an overall impression of immorality and non-conformity with an alleged "Indian culture."

31 Some further observations are worth summing up. Despite the nature of commodification that is attached to commercial advertising, it is undeniable that in reality an individualized decision to live together causes changes in family relationships. As I have noted above, many viewers definitely see this aspect in "Surprise Visit." We are confronted with two rudimentary altered relations: a different concept of partnership that is framed as egalitarian and self-chosen, and a different form of parent-child relationship, that is less paternalistic and authoritative. Within the second context, the role of the father as a decision-making patriarch is remarkably reduced. It is the mother (in-law) who needs to be pacified and convinced. But overall, the central themes-in the analyzed YouTube comment section as well as the popular discourse on live-in relationships-appear to be not solely holy matrimony or the relationship between Chirag and Pallavi as depicted in the advertisement. Additionally, the issue of controlling sexuality seems to override all other aspects and determines whether a constellation is acceptable or not to the respective viewers.

\section{BIBLIOGRAPHY}

Agrawal, Anuja. 2015. "Cyber-matchmaking among Indians: Re-arranging Marriage and Doing 'Kin Work.”' South Asian Popular Culture 13(1):15-30.

Ahmad, Imtiaz. 2003. "Between the Ideal and the Real: Gender Relations within the Indian Joint Family." Pp. 36-83 in Family and Gender: Changing Values in Germany and India, edited by M. Pernau, I. Ahmad and H. Reifeld. New Delhi: Sage Publications.

Ahmed, Sameera. 2010. “Are We Ready to Accept Live-in Relationships?” Youth Ki Awaaz. Mouthpiece for the Youth, January 21. Retrieved November 28, 2012 (http:// www.youthkiawaaz.com/2010/01/are-we-ready-to-accept-live-in/\#WZE6gMp2BF7p5JKK.99).

Balachandran, Manu. 2016. "In Conservative India, a Startup is Helping Couples to Find a Room." Quartz India, April 10. Retrieved November 30, 2016 (http://qz.com/655949/in-conservativeindia-a-startup-is-helping-unmarried-couples-find-a-room-and-taking-on-moral-policing/).

BBC News India. 2012. "In Pictures: Finding Love in the Autumn of Life," August 3. Retrieved September 20, 2012 (http://www.bbc.co.uk/news/world-asia-india-19059436).

Beniger, James. 1986. The Control Revolution: Technological and Economic Origins of the Information Society. Cambridge, MA: Harvard University Press. 
Bergmann, Jörg. 2006. “Qualitative Methoden der Medienforschung: Einleitung und Rahmung." Pp. 13-41 in Qualitative Methoden der Medienforschung, edited by R. Ayaß and J. Bergmann. Reinbek bei Hamburg: Rowohlt.

Brosius, Christiane. 2013. "Love Attacks. Romance and Media Voyeurism in the Public Domain." Pp. 225-86 in Sexuality Studies, edited by S. Srivastava. New Delhi, Oxford: Oxford University Press.

Carter, Steven and Julia Sokol. 1987. Men Who Can't Love: When a Man's Fear Makes Him Run from Commitment (and What a Smart Woman Can Do about It). New York: M. Evans.

Chakraborty, Kabita. 2012. "Virtual Mate-seeking in the Urban Slums of Kolkata, India." South Asian Popular Culture 4:1-20.

Chatterjee, Partha. 1989. "Colonialism, Nationalism, and Colonialized Women: The Contest in India." American Ethnologist 16(4):622-33.

Chatterji, Rohini. 2015. "Marriage Certificate, Please! No Place to Live in Sin in 'Modern' Mumbai." Firstpost, August 13. Retrieved November 30, 2016 (http://www.firstpost.com/specials/ marriage-certificate-please-no-place-to-live-in-sin-in-modern-mumbai-2371202.html).

Chaudhuri, Maitrayee. 2001. "Gender and Advertisements: The Rhetorics of Globalization." Women's Studies International Forum 24(3-4):373-85.

Chauhan, Gajendra Singh. 2010. Language, Media and Society: Essence of Advertising Communication. New Delhi: Rawat Publications.

Choudhary, Amit Anand. 2015. "Live-in Relationships Now Acceptable Norm in Society: SC." The Times of India, July 24. Retrieved January 9, 2017 (http://timesofindia.indiatimes.com/india/Livein-relationships-now-acceptable-norm-in-society-SC/articleshow/48195514.cms).

Collingham, Elizabeth. 2006. Curry: A Tale of Cooks and Conquerors. London: Vintage Books.

Dasgupta, Sanjukta and Malashri Lal. 2007. The Indian Family in Transition: Reading Literary and Cultural Texts. Thousand Oaks, CA: Sage Publications.

Devnath, Shiva. 2015. "Mumbai: Couples Picked up from Hotel Rooms, Charged with 'Public Indecency." Mid-Day.com, August 8. Retrieved November 30, 2016 (http://www.mid-day.com/ articles/mumbai-couples-picked-up-from-hotel-rooms-charged-with-public-indecency/16437186 ) .

Donner, Henrike. 2011. Being Middle-class in India: A Way of Life. London and New York: Routledge.

Facebook. 2015. "Famous Live-In Relationships in India \& Abroad," July 28. Retrieved November 29, 2016 (https://www.facebook.com/pg/Live-in-Relationship-Cohabitation-

India-819116471519602/photos/?tab=album\&album_id=819142058183710).

Facebook. Group “Live-In Relationship/Cohabitation in India.” Retrieved November 30, 2016 ( https://www.facebook.com/Live-in-Relationship-Cohabitation-India-819116471519602/).

Fernandes, Leela. 2000. "Nationalizing 'the Global': Media Images, Cultural Politics and the Middle Class in India." Media, Culture \& Society 22(5):611-28.

Fernandes, Leela. 2006. India's New Middle Class: Democratic Politics in an Era of Economic Reform. Minneapolis and London: University of Minnesota Press.

Firstpost. 2015. "SC Says Woman in Live-in Relationship to be Considered Wife unless Proven Otherwise," April 13. Retrieved November 29, 2016 (http://www.firstpost.com/india/sc-sayswoman-live-relationships-considered-wife-unless-proven-otherwise-2194155.html). 
Gabler, Mette. 2010. "The Good Life: Buy 1 Get 1 Free. Messages of Outdoor Advertising for Social Change in Urban India." Südasien-Informationen, May 6. Retrieved January 5, 2016 (http:// www.suedasien.info/schriftenreihe/2869).

Ganguly-Scrase, Ruchira and Timothy Scrase. 2009. Globalisation and the Middle Classes in India: The Social and Cultural Impact of Neoliberal Reforms. New York: Routledge.

Grover, Shalini. 2011. Marriage, Love, Caste, and Kinship Support: Lived Experiences of the Urban Poor in India. New Delhi: Social Science Press.

Gudermuth, Kerstin. 2006. “Liebe Jenseits der Ehe.” Südasien.info, January 23. Retrieved September 11, 2012 (http://www.suedasien.info/analysen/1668).

Gugler, Thomas. 2014. "New Media, Neosexual Activism and Diversifying Sex Worlds in PostLiberalization India." Pp. 143-66 in Studying Youth, Media and Gender in Post-Liberalisation India: Focus on and beyond the "Delhi Gang Rape," edited by N.-C. Schneider and F.-M. Titzmann. Berlin: Frank \& Timme.

Hall, Stuart. [2001] 2006. "Encoding/Decoding." Pp. 163-73 in Media and Culture Studies Keyworks (Rev. ed.), edited by M. G. Durham and D. M. Kellner. Malden, MA: Blackwell Publishing.

Hepp, Andreas. 2009. "Transculturality as a Perspective: Researching Media Cultures Comparatively.” Forum: Qualitative Social Research 10(1). Retrieved April 4, 2017 (http://nbnresolving.de/urn:nbn:de:0114-fqs0901267).

Illouz, Eva. 1997. Consuming the Romantic Utopia: Love and the Cultural Contradictions of Capitalism. Berkeley: University of California Press.

Indiankanoon. 2010. “D. Velusamy vs D. Patchaiammal on 21 October, 2010.” Retrieved November 29, 2016 (https://indiankanoon.org/doc/1521881/).

Jayachandran, Jesna. 2014. "Outrage, Debate or Silence: An Analysis of Reader Comments and Online Rape News." Pp. 45-77 in Studying Youth, Media and Gender in Post-Liberalisation India: Focus on and beyond the "Delhi Gang Rape," edited by N.-C. Schneider and F.-M. Titzmann. Berlin: Frank \& Timme.

John, Mary E. 2005. “Feminist Perspectives on Family and Marriage: A Historical View.” Economic and Political Weekly 40(8):712-15.

Kantowsky, Detlef. 2002. "Mother India ruft ihre Kinder. Bemerkungen zur Persons of Indian Origin Card, besonders in Mauritius." Internationales Asienforum: International Quarterly for Asian Studies 33(1-2):127-43.

Kaur, Ravinder and Ishita Shruti. 2016. “Mobile Technology and 'Doing Family' in a Global World: Indian Migrants in Cambodia." Pp. 73-91 in Mobile Communication and the Family: Asian Experiences in Technology Domestication, edited by S.S. Lim. Dordrecht: Springer.

Khandelwal, Meena. 2009. "Arranging Love: Interrogating the Vantage Point in Cross-Border Feminism.” Sign: Journal of Women in Culture and Society 32(3):583-609.

Kim, Youna. 2008. "Introduction: The Media and Asian Transformations." Pp. 1-24 in Media Consumption and Everyday Life in Asia, edited by Y. Kim. New York: Routledge.

Mahapragya, Acharya, Avul Pakir Jainulabdeen and Abdul Kalam. 2014. The Family and the Nation. Noida: Harper Collins.

Mani, Bakirathi and Latha Varadarajan. 2005. "The Largest Gathering of the Global Indian Family: Neoliberalism, Nationalism, and Diaspora at Pravasi Bharatiya Divas." Diaspora: A Journal of Transnational Studies 14(1):45-74. 
Mankekar, Purnima. 1999. Screening Culture, Viewing Politics: An Ethnography of Television, Womanhood, and Nation in Postcolonial India. Durham, NC: Duke University Press.

Mankekar, Purnima. 2004. "Dangerous Desires: Television and Erotics in Late Twentieth-Century India." The Journal of Asian Studies 63(2):403-31.

Mankekar, Purnima. 2009. “'Women-Oriented' Narratives and the New Indian Woman.” Pp. 13550 in The Indian Public Sphere: Readings in Media History, edited by A. Rajagopal and C. A. Bayly. New Delhi: Oxford University Press.

Mey, Günter and Katja Mruck. 2007. Grounded Theory Reader. Köln: ZHSF (HSR Supplement, 19).

Michaels, Axel. 2006. Der Hinduismus: Geschichte und Gegenwart. Munich: Beck.

Mody, Perveez. 2006. "Kidnapping, Elopement and Abduction: An Ethnography of Love-marriage in Delhi." Pp. 331-44 in Love in South Asia: A Cultural History, edited by F. Orsini. Cambridge: Cambridge University Press.

Munshi, Shoma. 1998. "Wife/Mother/Daughter-in-law: Multiple Avatars of Homemaker in 1990s Indian Advertising." Media, Culture \& Society 20(4):573-91.

Nagpal, Mohita. 2011. “Single and 'Living-in' at 50." MidDay, December 19. Retrieved September 20, 2012 (http://www.mid-day.com/lifestyle/2011/dec/191211-Single-and-living-in-at-50.htm).

Nast, Michael. 2016. Ist das Liebe, oder kann das weg? Vom sonderbaren Verhalten der Generation Beziehungsunfähig. Berlin: Ullstein.

Nettikkara, Samiha. 2016. “Indians 'Swipe Left' on Desi Tinder Ad.” BBC news, May 11. Retrieved December 1, 2016 (http://www.bbc.com/news/world-asia-india-36264101).

Ohm, Britta. 2001. Ist dies eine Invasion? Transnationale Sender und Nationales Fernsehen in Indien. Hamburg: Lit Verlag.

Patel, Tulsi. 2005. The Family in India: Structure and Practice. New Delhi: Sage Publications.

Phadke, Shilpa. 2005. "Some Notes towards Understanding the Construction of Middle-Class Urban Women's Sexuality in India." Pp. 67-81 in Sexuality, Gender, and Rights: Exploring Theory and Practice in South and Southeast Asia, edited by G. Misra and R. Chandiramani. New Delhi: Sage Publications.

Phadke, Shilpa. 2015. "Risking Feminism? Voices from the Classroom." Economic and Political Weekly 50(17):63-70.

Poggendorf-Kakar, Katharina. 2003. "Virtuous Mother, Virile Hero and Warrior Queen: The Conception of Gender and Family in Hindutva." Pp. 179-95 in Family and Gender: Changing Values in Germany and India, edited by M. Pernau, I. Ahmad and H. Reifeld. New Delhi: Sage Publications.

Prakash, Satya. 2013. “Live-in Relationship neither a Crime nor a Sin: SC.” Hindustan Times, December 1. Retrieved January 9, 2017 (http://www.hindustantimes.com/india/live-inrelationship-neither-a-crime-nor-a-sin-sc/story-m6di9Hgp8CFxefCRrOvndP.html).

Rajagopal, Arvind. 2000. Politics after Television: Hindu Nationalism and the Reshaping of the Public in India. Cambridge: Cambridge University Press.

Rajan, Rajeswari Sunder. 1993. Real and Imagined Women: Gender, Culture and Postcolonialism. London: Routledge.

Ramgopal, Akanksha. 2012. "Event to Find a Match for Lonely Senior Citizens on June 12." The Indian Express (Pune), June 3. Retrieved September 20, 2012 (http://www.indianexpress.com/ news/event-to-find-a-match-for-lonely-senior-citizens-on-june-12/957159). 
Rao, Anupama. 2005. "Sexuality and the Family Form." Economic and Political Weekly 40(8):715-18.

Shah, Chayanika. 2005. "Marriage, Family and Community: A Feminist Dialogue." Economic and Political Weekly 40(8):709.

Sharma, K. L. 2011b. Culture, Stratification and Development. Jaipur: Rawat Publications.

Sharma, Radha. 2011a. "Now, Senior Citizens Look for Love and Live-ins." The Times of India (Ahmedabad), November 3. Retrieved September 20, 2012 (http:// articles.timesofindia.indiatimes.com/2011-11-03/ahmedabad/30354374_1_live-in-relationshipslive-in-partner-live-in-companions).

Shukla, Akhilesh. 2015. "India's Metros are Becoming a Breeding Ground for Live-in Relationships." India TV, September 10. Retrieved January 9, 2017 (http://www.indiatvnews.com/ lifestyle/news/indias-metros-breeding-ground-for-live-in-relationships-4913.html).

Singhal, Arvind and Everett M. Rogers. 1989. "Prosocial Television for Development in India." Pp. 331-50 in Public Communication Campaigns ( $2^{\text {nd }}$ ed.), edited by R. E. Rice and C. Atkin. Thousand Oaks, CA: Sage.

StayUncle. Retrieved December 1, 2016 (http://stayuncle.com/home).

Swener.com. "Live-in Is the In." Retrieved October 30, 2015 (http://www.swener.com/live-in-isthe-new-in).

Titzmann, Fritzi-Marie. 2011a. "Medialisation and Social Change: The Indian Online Matrimonial Market as a New Field of Research." Pp. 49-66 in Social Dynamics 2.0. Researching Change in Times of Media Convergence: Case Studies from the Middle East and Asia, edited by N.-C. Schneider and B. Gräf. Berlin: Frank \& Timme.

Titzmann, Fritzi-Marie. 2011b. "Matchmaking 2.0: The Representation of Women and Female Agency in the Indian Online Matrimonial Market." Internationales Asienforum. International Quarterly for Asian Studies 42(3-4):239-56.

Titzmann, Fritzi-Marie. 2013. "Changing Patterns of Matchmaking. The Indian Online Matrimonial Market.” Asian Journal of Women's Studies 19(4):64-94.

Titzmann, Fritzi-Marie. 2014. “'The Voice of the Youth': Locating a New Public Sphere between Street Protest and Digital Discussion." Pp. 79-111 in Studying Youth, Media and Gender in PostLiberalisation India: Focus on and beyond the "Delhi Gang Rape," edited by N.-C. Schneider and F.-M. Titzmann. Berlin: Frank \& Timme.

Uberoi, Patricia. 2001a. "Imagining the Family: An Ethnography of Viewing Hum Aapke Hain Koun...!” Pp. 309-51 in Pleasure and the Nation, edited by R. Dwyer and C. Pinney. New Delhi: Oxford University Press.

Uberoi, Patricia. 2003. “The Family in India: Beyond the Nuclear versus Joint Debate.” Pp. 1061103 in Oxford India Companion to Sociology and Social Anthropology, edited by V. Das. Delhi: Oxford University Press.

Wadhwani, Samiksha. 2013. "It's All about Today's Generation." Gen-Today, March 7. Retrieved January 3, 2016 (http://d-samiksha.blogspot.de/2013/03/cohabitation-in-india.html).

Webster, Frank. 2002. Theories of the Information Society. Cambridge: Routledge.

Yadav, Alok Kumar and Santosh Yadav. 2011. "Live-in Relationship: The Legality of Unconventional Relationships in India." Pragyaan: Journal of Law: Institute of Management Studies Dehradun 1(1):23-28.

Videos 
99acres.com. 2015. "W99acres.com New TV Ad: Rent Anytime on 99acres.com." YouTube, May 15. Retrieved December 1, 2016 (https://www.youtube.com/watch?v=PH3fkeXfqzs).

Myntra. 2015. “Anouk: Bold is Beautiful/The Visit." YouTube, May 26. Retrieved December 1, 2016 (https://www.youtube.com/watch?v=Ef27m5ocK6Q).

Red Label India. 2015. “Red Label: Surprise Visit.” YouTube, May 21. Retrieved December 1, 2016 ( https://www.youtube.com/watch?v=7pOFqpZAKds).

Red Label India. 2014. "Red Label New Ad: Neighbours." YouTube, April 1. Retrieved December 1, 2016 (https://www.youtube.com/watch?v=tQuddKFhfFA).

Tanishq Jewellery. 2013. “Tanishq wedding film.” YouTube, October 24. Retrieved December 1, 2016 (https://www.youtube.com/watch?v=P76E6b7SQs8).

\section{NOTES}

1. A Facebook group called "Live-In Relationship/Cohabitation in India" posted a photo album displaying "Famous Live-In Relationships in India \& Abroad," which included many celebrities from the film industry, e.g. film stars Freida Pinto and Dev Patel. The group has 463 likes (retrieved November 29, 2016).

2. I draw from various media resources and analyze them, following the grounded theory method (Mey and Mruck 2007). It is important to emphasize that I deal with representations which can only reflect attitudes. I do not base my observations on extensive field work.

3. In the Velusamy vs Patchaiammal case (2010), the Supreme Court held that "a relationship in the nature of marriage" must fulfill the following criteria: (a) the couple must hold themselves out to society as being akin to spouses: (b) they must be of legal age to marry; (c) they must be otherwise qualified to enter into a legal marriage, including being unmarried; (d) they must have voluntarily cohabited and held themselves out to the world as being akin to spouses for a significant period of time, and in addition the parties must have lived together in a "shared household" as defined in Section 2(s) of the Act. Merely spending weekends together or a onenight stand would not constitute a "domestic relationship." The case also held that if a man has a "keep" whom he maintains financially and uses mainly for sexual purpose and/or as a servant it would not be a relationship in the nature of marriage. (CRIMINAL APPEAL NOS. 2028-2029 of 2010). The complete judgment of "D.Velusamy vs D.Patchaiammal on 21 October, 2010" (Indiankanoon 2010) is available online.

4. The dominant Hindu, upper caste, and middle class perspective falls short of acknowledging the diversity of social realities. John states that "significant debates on the intersections of caste and gender focus on paradoxes such as greater freedoms among the so-called lower castes and in Dalit family structures, compared to the strictures placed on upper caste women and their sexuality" (2005:714). Chakraborty (2012) and Grover (2011) refer to deviating realities in India's poor urban areas where upward social mobility is more important than sexual purity. Similarly, Gudermuth states that upper classes and celebrities are somewhat excluded from the pressure of social conformity that particularly burdens the middle classes as representatives of a normative social order (2006).

5. See Sharma (2011a); Nagpal (2011); Ramgopal (2012).

6. StayUncle: http://stayuncle.com/home.

7. Other highly medialized examples of moral policing include attacks in Meerut parks on couples (2005), the Mangalore Pub attack (2009), debates centering around practices associated with Valentine's Day celebrations as “anti-Indian” and obscene (Brosius 2013:257, 266).

8. See Choudhary (2015); Prakash (2013); Shukla (2015). 
9. An early example is Mahesh Bhatt's film "Arth" (1982), a semi-autobiographical representation of the director's extramarital relationship with Parveen Babi. Recent Indian films featuring livein relationships include: "Salaam Namaste" (dir. Siddharth Anand, 2005), "Fashion" (dir. Madhur Bhandarkar, 2008), "Cocktail” (dir. Homi Adajania, 2012), "Shuddh Desi Romance (dir. Maneesh Sharma, 2013), "I, Me aur Main” (dir. Kapil Sharma, 2013), "Katti Batti” (dir. Nikkhil Advani, 2015). In Indian commercial cinema, however, extramarital affairs and adultery regularly end with negative consequences. Premarital dating is typically resolved either through a socially sanctioned marriage, which is then called "love-cum-arranged," the couple's separation, or an appropriate marriage with another partner (Gudermuth 2006).

10. Red Label India: Red Label - Surprise Visit, published on May 21, 2015. Links to YouTube videos are listed below the literature references.

11. The advertisement's dialogues are spoken in Hindi.

12. A dupatta is a long shawl or stole worn over the chest and thrown back around the shoulders. It is part of a salwar kameez, a traditional dress for women in South Asia consisting of loose pants and a long shirt. The covering of the upper female torso is considered a sign of modesty and decency.

13. Red Label India 2014.

14. Tanishq Jewellery 2013.

15. Myntra, 2015.

16. 99 acres.com, 2015.

17. On the state ideology of developmentalism with regards to television see: Singhal and Rogers (1989), Rajagopal (2001), Ohm (2001).

18. For research on information society or information capitalism, see e.g. Beniger (1986); Webster (2002); and the works of Manuel Castells.

19. For studies on the online matrimonial market and virtual friendships in India see: Agrawal (2015), Chakraborty (2012), Titzmann (2011a, 2011b, 2013).

20. "Desi" is a colloquial term derived from the Hindi word deś (देश) for land/homeland. It denotes people, objects or activities that either originate in South Asia or are perceived as typical.

21. In the nationalist discourse of the $19^{\text {th }}$ and early $20^{\text {th }}$ century, the "New Indian Woman" denotes a non-westernized, politically emancipated and inherently Indian woman who is a fortress of essential "Indianness" and a supporter of Indian nationalism. Similar to her contemporary counterpart, the colonial concept was located in the educated middle class.

22. As one anonymous reviewer suggested, Collingham's exploration of Indian food history may point to an additional possible interpretation of how a tea brand and the promotion of family (and communal) harmony are interconnected (Collingham 2006:188). She describes how teadrinking was introduced by the British and-according to Collingham's assessment-has contributed to the process of weakening intercaste differences. This leads us to Red Label's slogan of "tea and togetherness" (Collingham 2006:201). Maybe this historical trajectory of drinking tea contributes-among many other factors-to the depiction of Chirag's mother accepting a cup of tea from a stranger like Pallavi.

23. I would like to thank the anonymous reviewer for pointing out these three main strands of interpretation and suggesting the term "consumerist progressivism."

24. For a more detailed methodological discussion on social media analysis see Jayachandran (2014) and Titzmann (2014).

25. Many viewers use a colloquial mix of Hindi and English language, so-called "Hinglish," which I explain only in relation to crucial terms or where an understanding for non-Hindi speakers appears difficult. Quotes from the comments include several spelling and grammatical mistakes. For the sake of authenticity I replicate them without correction. The name of the viewer who posted the comment is given in parentheses to indicate authorship. 
26. I have made a similar observation about a strong dissociation from feminism as an ideological movement in an analysis of blog posts on the "Delhi gang rape case" (Titzmann 2014:94).

27. "Kaise parents ne kuch react nahi kiya [How (i.e. why) did the parents not react] ?????? my mother would have killed me" (Fauziya Maskati); "I'm a feminist and if there's one thing that seemed wrong about this ad it's that any guy's traditional parents would just be okay with this over one fucking cup of chai." (Sakina Sehgal)

28. Gorā (गोरा): white (Hindi). It is used as a colloquial term for foreigners from the "West."

29. See: Mani and Varadarajan (2005) who write on the Pravasi Bharatiya Divas as "The Largest Gathering of the Global Indian Family" or Kantowsky (2002) who wrote an article on the new PIO card "Mother India ruft ihre Kinder" ("Mother India calls her children").

30. In Germany, the impressive success of Michael Nast's book on a generation that he calls "relationship-incapable" (2010) is but one example. Steven Carter's “Men Who Can't Love" (1987) is an earlier counterpart from the shelves of American relationship advice literature.

31. E.g. the Facebook group "Live-In Relationship/Cohabitation in India." The cover photo shows a tropical sunset with the words FREEDOM written across the picture (retrieved November 30, 2016).

32. In this context "hookup" denotes a non-committed physical encounter.

33. For further studies on middleclassness, gendered family relations, and its representations in India, see Fernandes (2006); Donner (2001); Ganguly-Scrase; Scrase (2009).

34. For detailed studies on the entanglement of patriarchal power relations and the joint family system, see Ahmad (2003); Patel (2005); Rao (2005); Uberoi (2003).

\section{ABSTRACTS}

A recent trend in television advertisement of staging unconventional social constellations includes an advertisement released by the tea brand Red Label in 2015 featuring a live-in couple facing an awkward family situation that eventually dissolves into intergenerational harmony. The one-minute commercial visualizes not only an alternative to the married couple but invites us to re-imagine the relationship between parents and children as well. Based on the assumption that society and media co-construct each other, this paper asks whether the act of rendering the unconventional visible is already a challenge to the idea of the Indian family. Further, it analyzes the conflictual online discourse evolving around the short film. In particular, looking at viewers' comments reveals conflicting attitudes that reflect different discourses in Indian society. Apart from the obvious topic of cohabitation, viewers "see" a multitude of interconnected themes reflected in the commercial and go on to discuss gender roles, sexuality and the visual symbols of "Indianness."

\section{INDEX}

Keywords: live-in relationships, advertising, family, social media, gender roles, sexuality, consumerism 


\section{AUTHOR}

\section{FRITZI-MARIE TITZMANN}

Institute for Indology and Central Asian Studies, Leipzig University, Germany 